\title{
Stannate Conversion Coatings for AM60B Magnesium Alloy
}

\author{
Suqiu Jia ${ }^{1, a}$, You Zhou ${ }^{1, b}$ and Shuyan Jia ${ }^{2, c}$ \\ ${ }^{1}$ Laboratory of Advanced Structural Materials, Ministry of Education, Changchun University of \\ Technology, Changchun 130012, China \\ 2Liaoyuan Industrial and commercial school, Liaoyuan 136002, China \\ ajiasuqiu@ccut.du.cn, b098377330@qq.com, jiiashuyan@126.com
}

\begin{abstract}
Keywords: Corrosion, Am60B,Stannate Conversion Coatings
Abstract. A stannate conversion coating was designed for AM60B magnesium alloys. The influences of temperature and time on the surface morphology and phase composition have been tested using scanning electron microscope (SEM) and X-ray diffraction (XRD), respectively.Additionally,potentiodynamic polarization tests have been used to estimate the corrosion resistance of unprotected and protected AM60B Magnesium alloy with a stannate conversion coating in $3.5 \% \mathrm{NaCl}$ solutions.Plenty of coating particles form a stannate coating at $80^{\circ} \mathrm{C}$,consisting of $\mathrm{MgSnO}_{3} \cdot 3 \mathrm{H}_{2} \mathrm{O}$. At different temperature the corrosion potential is nearly the same as $-1.31 \mathrm{~V}$ while with time increase it moves towards to positive and reached to $-1.01 \mathrm{~V}$. Both of corrosion potentials of stannate conversion coatings are more positive than that of AM60B substrate $(-1.48 \mathrm{~V})$.
\end{abstract}

\section{Introduction}

Magnesium alloys are promising materials for applications where weight reduction is essential, such as automotive,aerospace, electronics, computer, mobile phone for low density, good mechanical properties, good castability [1-3].However,the production and use of magnesium alloys have been fairly limited because of its poor corrosion resistance. So many methods have been proposed used to protection of magnesium alloy corrosion. Surface treatments are easy and simple for corrosion protection. The chemical conversion treatments applied to magnesium alloys generally use cerate [4-6], permanganate [7,8], fluoride [9], phosphate [10-12] and stannate[13-15] in the baths. Such coatings provide a limited corrosion resistance. Recently, stannate treatments have been investigated for the improvement of the corrosion resistance of magnesium and its alloys. In this paper, conversion coatings on AM60B were fabricated and morphology, composition and corrosion resistance were evaluated.

\section{Experimental}

The specimens were AM60B die cast magnesium alloy with dimensions $15 \mathrm{~mm} \times 10 \mathrm{~mm} \times 2 \mathrm{~mm}$. The normal compositions are 5.6-6.4\% $\mathrm{Al}$ and $0.26-0.5 \% \mathrm{Mn}$ and the balance $\mathrm{Mg}$. The process operations included Alkaline Cleaning,acid cleaning and chemical conversion. The details were given in Table 1.The morphology of the coatings were examined by scanning electron microscopy (SEM,JEOL 5600). The phase of the deposits was confirmed by X-ray diffraction(XRD) Polarization curves of the specimens were measured in an electrolytic cell containing about $500 \mathrm{ml}$ $3.5 \%$ (mass fraction) $\mathrm{NaCl}$ solution at room temperature using Ivium stat electrochemical measurement system. The corrosion potential of the coating was evaluated and optimized bath composition parameters were determined.

\section{Results and Discussion}

Morphologies of conversion coatings. Fig. 1 shows that the analogizes of stannate conversion coatings for immersion in a stannate bath for $20 \mathrm{~min}$ at different temperature. As can be seen in the figure, the coating particles increase with increasing bath temperature. At $40^{\circ} \mathrm{C}(\mathrm{Fig} .1 \mathrm{a})$, there is no 
coating particles formed on the AM60B substrate and only net- $\mathrm{Mg}(\mathrm{OH})_{2}$ formed on the surface. When the bath temperature reaches $60^{\circ} \mathrm{C}$, slight coating particles deposit on the surface (Fig.1b) plenty of coating particles form a stannate coating at $80^{\circ} \mathrm{C}$ (Fig1.c) but the surface is not covered completely by the coating particles. This means that, in the condition of $\mathrm{pH} 12$ at $80^{\circ} \mathrm{C}$, increasing $\mathrm{Mg}^{2+}$ ions near the surface does promote further deposition of the coating film. Fig.2 shows morphologies of the conversion coatings at $80^{\circ} \mathrm{C}$ for different time. The average size of the coating particles is not dependent on time and the number of particles per unit surface area increase with increasing time. During the immersion time from $10 \mathrm{~min}$ to $30 \mathrm{~min}$, the coating particles increase significantly, from less particles and more particles to massive particles which are almost full of the surface.However, there is crevices among the particles in the coating formed for $30 \mathrm{~min}$. $\mathrm{The}_{\mathrm{Mg}}^{2+}$ ions present in the coating bath near the surface are efficiently used for nucleation and growth of coating particles with time increase.It was found that the stannate coatings on $\mathrm{Mg}$ and its alloys are formed by initial dissolution of substrate $\mathrm{Mg}$ followed by deposition of coating particles after concentrations of $\mathrm{Mg}^{2+}$ and stannate ions near the substrate surface in the bath reach critical

Table 1 The process of operation

\begin{tabular}{|c|c|c|c|}
\hline $\begin{array}{l}\text { Stag } \\
\mathrm{e}\end{array}$ & Process & Operation & Condition \\
\hline 1 & Ultrasonic degreasing & Acetone & $5-10 \mathrm{~min}$ \\
\hline 2 & Alkaline cleaning & $40[\mathrm{~g} / \mathrm{L}]$ & $60{ }^{\circ} \mathrm{C}, 10 \mathrm{~min}$ \\
\hline 3 & Acid pickling & $10[\mathrm{ml} / \mathrm{L}]$ & $\begin{array}{l}\text { Room temperature, } \\
45 \mathrm{~s}-1 \mathrm{~min}\end{array}$ \\
\hline \multirow[t]{4}{*}{4} & \multirow[t]{4}{*}{ Chemical conversion } & $\mathrm{Na}_{2} \mathrm{SnO}_{3} \cdot 3 \mathrm{H}_{2} \mathrm{O} \quad 25[\mathrm{~g} / \mathrm{L}]$ & \multirow{4}{*}{$80{ }^{\circ} \mathrm{C}, 30 \mathrm{~min}, \mathrm{pH} 12$} \\
\hline & & $\mathrm{Na}_{4} \mathrm{P}_{2} \mathrm{O}_{7} \cdot 10 \mathrm{H}_{2} \mathrm{O} \quad 40[\mathrm{~g} / \mathrm{L}]$ & \\
\hline & & $\mathrm{CH}_{3} \mathrm{COONa} \quad 10[\mathrm{~g} / \mathrm{L}]$ & \\
\hline & & $10[\mathrm{~g} / \mathrm{L}]$ & \\
\hline
\end{tabular}

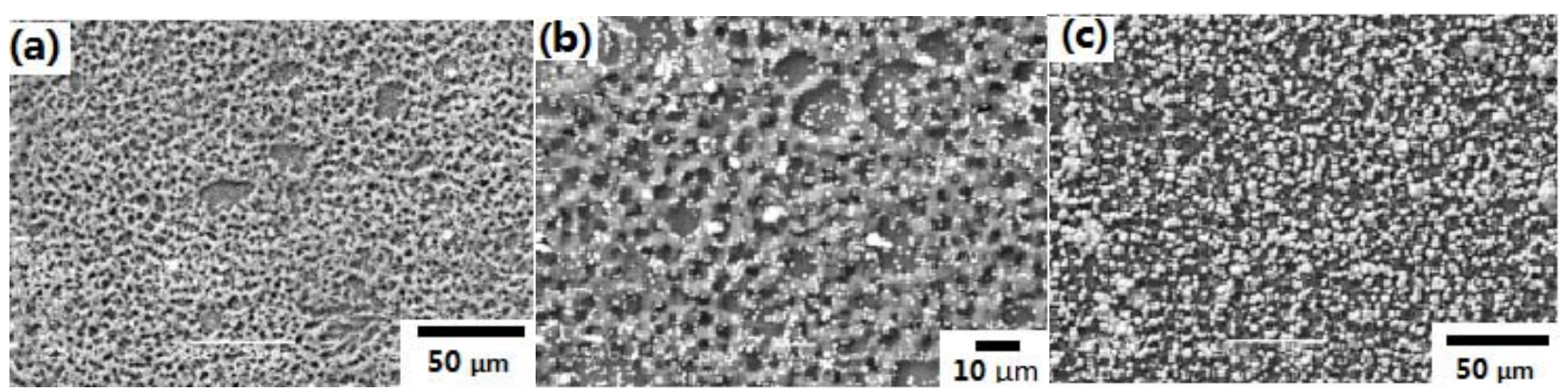

Fig. 1 Morpologies of the conversion coating for different temperature (a) $40^{\circ} \mathrm{C}$, (b), $60^{\circ} \mathrm{C}$ and (c) $80^{\circ} \mathrm{C}$ for $20 \mathrm{~min}$
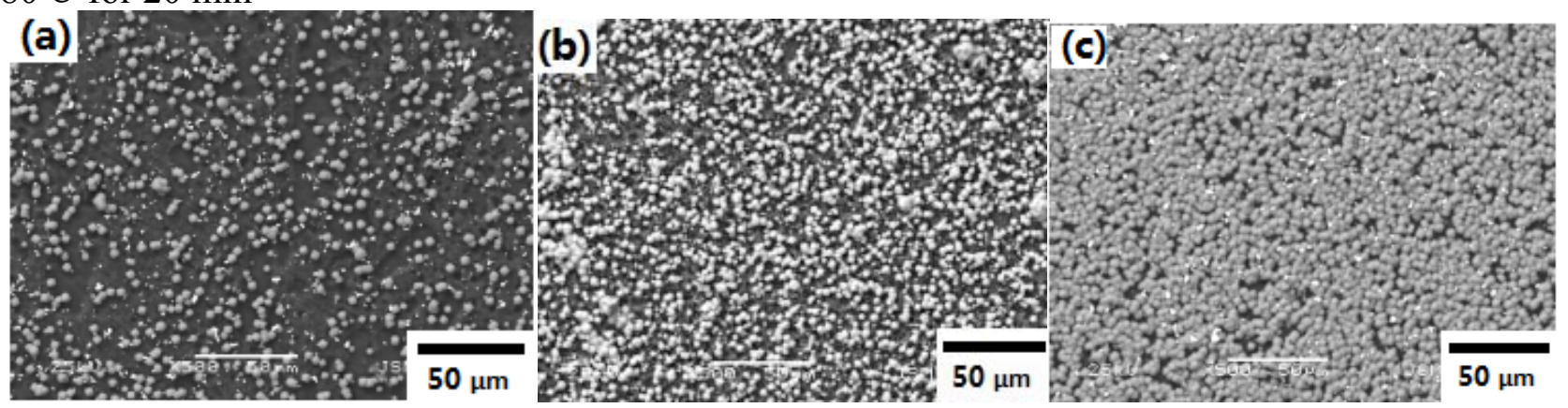

Fig. 2 Morpologies of the conversion coating at $80^{\circ} \mathrm{C}$ for different time (a) $10 \mathrm{~min}$,(b) $20 \mathrm{~min}$ and (c) $30 \mathrm{~min}$

concentrations and the coating particles are mainly composed of hydrated magnesium stannate particles, $\mathrm{MgSnO}_{3} \cdot 3 \mathrm{H}_{2} \mathrm{O}$ [14].

Phase Composition. In Fig.3, the phase composition of the stannate conversion coating consists of $\mathrm{Mg}$, Sn and $\mathrm{MgSnO}_{3} \cdot 3 \mathrm{H}_{2} \mathrm{O}$ by XRD pattern. $\mathrm{Mg}$ phase proves that the coating has not covered the 
magnesium alloy substrate and crevices among the particles are exposed. AM60B die cast alloy consists of the primary $\alpha$ phase and the $\beta$ second phase and in general, the $\beta$ phase is chemically nobler than the $\alpha$ phase in the AM60B. The formation of the stannate conversion coating on $\mathrm{Mg}$ alloys occurs when sufficient $\mathrm{Mg}^{2+}$ are dissolved from the $\mathrm{Mg}$ substrate, as shown in reactions (1) and (2).Sn appears on the coating because $\mathrm{SnO}_{3}{ }^{2-}$ may get electrons and be reduced into $\mathrm{Sn}[1]$.

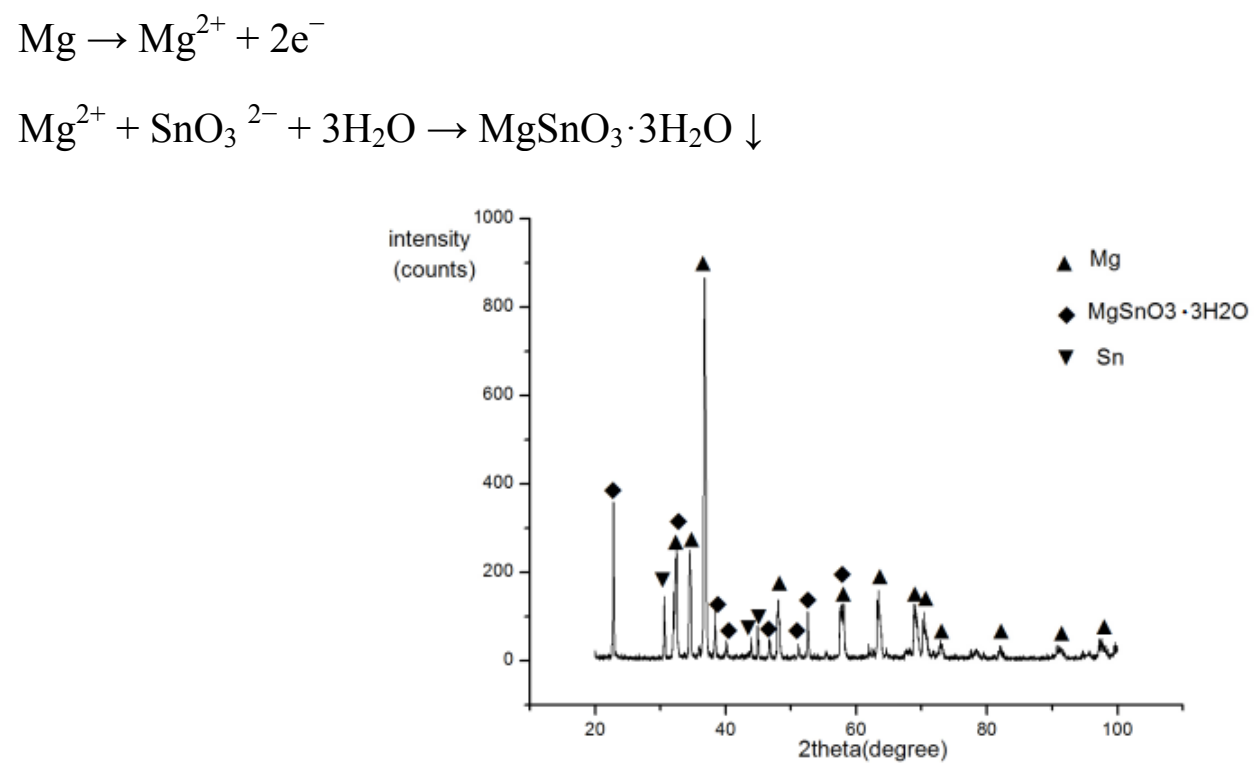

Fig,3 XRD pattern of the stannate conversion coating at $80^{\circ} \mathrm{C}$ for $30 \mathrm{~min}$

Potentiodynamic Polarization Curves. Potentiodynamic polarization curves of the coatings formed at different temperature and time in $3.5 \% \mathrm{NaCl}$ solution are presented in Fig.4 and Fig.5 respectively. As it can be seen, stannate coatings on AM60B alloy can improve the corrosion resistance. The corrosion potential of alloy AM60B $(-1.48 \mathrm{~V})$ is more negative than that of the stannate coatings $(-1.31$ to $1.01 \mathrm{~V})$, from which it could be deduced that the tendency towards corrosion has decreased through stannate conversion coating. At different temperature the corrosion potential is nearly the same as $-1.31 \mathrm{~V}$ while it moves towards to positive and reached to $-1.01 \mathrm{~V}$ for 30 min immersion in stannate bath with time increase.

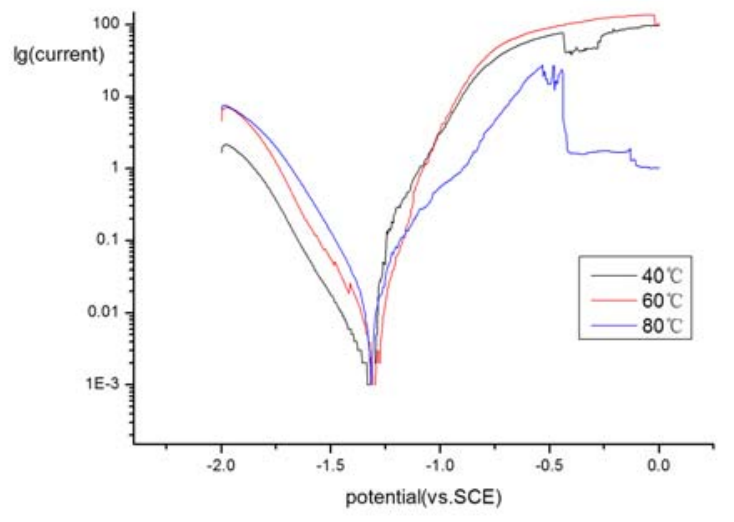

Fig.3 polarization curves of the stannate conversion coatings at different temperature for AM60B alloy in $3.5 \% \mathrm{NaCl}$ solution

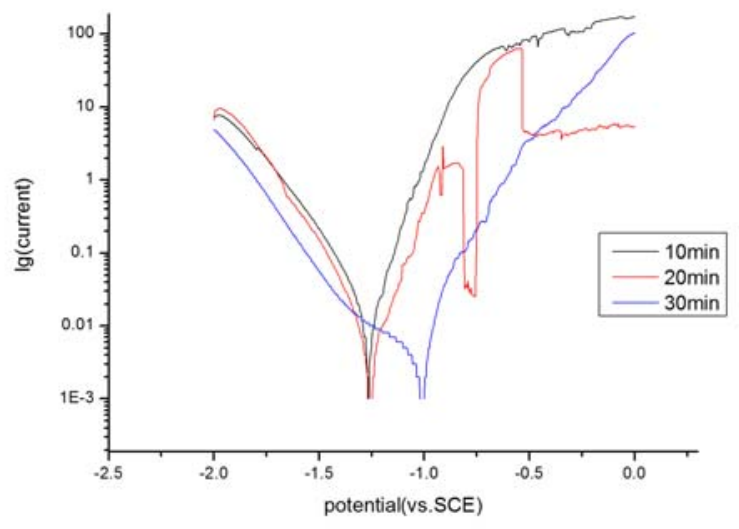

Fig.4 polarization curves of the stannate conversion coatings at different time for AM60B alloy in $3.5 \% \mathrm{NaCl}$ solution 


\section{Conclusions}

A stannate conversion coating conversion coating was obtained for AM60B magnesium alloys. The influences of temperature and time on the surface morphologies and phase composition were tested and potentiodynamic polarization curves were used to determine the corrosion resistance of the coatings on AM60B. The coating particles increase with increasing bath temperature and plenty of coating particles form a stannate coating at $80^{\circ} \mathrm{C}$ but they do not covered completely the surface of AM60B alloy. The average size of the coating particles is not dependent on time and the number of particles per unit surface area increase significantly with increasing immersion time from $10 \mathrm{~min}$ to $30 \mathrm{~min}$. the phase composition of the stannate conversion coating consists of $\mathrm{Mg}$, $\mathrm{Sn}$ and $\mathrm{MgSnO}_{3} \cdot 3 \mathrm{H}_{2} \mathrm{O}$. The tendency towards corrosion has decreased through stannate conversion coating for AM60B .At different temperature the corrosion potential is nearly the same as $-1.31 \mathrm{~V}$ while with time increase it moves towards to positive and reached to $-1.01 \mathrm{~V}$.Both corrosion potentials are more positive than that of AM60B substrate $(-1.48 \mathrm{~V})$.

\section{Acknowledgements}

This work was financially supported by the project of education department of Jilin Province (2011097) and Undergraduate Training Programs for Innovation and Entrepreneurship of Changchun University of Technology (2015cxcy030).

\section{References}

[1] N. V. Phuong, K. H. Lee, D. Chang, S. Moon: Corro.Sci. Vol. 74 (2013), p.314

[2] J.E. Gray, B. Luan: J. Alloy Compd. Vol. 33 (2002), p. 88

[3] S. Pommiser, J. Frayret, A. Gastebon, M. Potin-Gautier: Corro.Sci. Vol. 84 (2014),p. 135

[4] M.F. Montemor, A.M. Simões, M.J. Carmezim: Appl. Surf. Sci. 253 Vol. (2007),p. 6922

[5] H. Ardelean, I. Frateur, P. Marcus:Corros. Sci. Vol. 50 (2008),p1907

[6] C. Wang, S.L. Zhu, F. Jiang, F.H. Wang: Corros. Sci.Vol. 51 (2009),p. 2916

[7] F. Zucchi, A. Frignani, V. Grassi, G. Trabanelli, C. Monticelli: Corros. Sci.Vol.49 (2007),p.4542

[8] Y.L. Lee, Y.R. Chu, W.C. Li, C.S. Lin: Corros. Sci. Vol.70 (2013), p.74

[9] K.Y. Chiu, M.H. Wong, F.T. Cheng, H.C. Man: Surf. Coat.Technol. Vol. 202 (2007) ,p590

[10] D. Song, R. Shan, F. Chen, E.-H. Zhang, Han,: Corros. Sci. Vol.51 (2009),p 62

[11] W.Q. Zhou, D.Y. Shan, E.-H. Han, W. Ke: Corros. Sci.Vol.50 (2008),p 329

[12] Y. Song, D. Shan, R. Chen, F. Zhang, E.-H. Han: Surf. Coat. Technol. Vol.203 (2009),p.1107

[13]H. H. Elsentriecy, K. Azumi, H. Konno:Electrochim. Acta Vol. 53 (2008) ,p.4267

[14]H. H. Elsentriecy , K. Azumi, H. Konno:Surf. Coat.Technol. Vol. 202 (2007),p. 532

[15]X.L. Liu , T. Zhang, Y.W. Shao, G. Z. Meng, F.H. Wang:Corros. Sci. Vol.52 (2010) ,p.892 